UDC 663.4(477.83/.86): «18/21»

DOI: 10.24919/2519-058x.12.177546

Volodymyr KLAPCHUK

PhD hab. (History), Professor, Head of the Department of Hotel, Restaurant and Resort Business, Vasyl Stefanyk Precarpathian National University, 9 Bogdan Khmelnycky street, Delyatyn, Ivano-Frankivsk region, Ukraine, postal code 78442 (volodymyr_klapchuk@ukr.net)

ResearcherID: D-4699-2019 (https://www.researcherid.com/rid/D-4699-2019)

ORCID: https://orcid.org/0000-0003-1788-794X

\title{
Mykhailo KLAPCHUK
}

PhD (Geography), Docent, Tourism department, Ivan Franko National University of Lviv, 18 Lypy street, Lviv, Ukraine, postal code 79020 (klapchuk.m@gmail.com)

ORCID: https://orcid.org/0000-0002-8835-7674

\section{Володимир КЛАПЧУК}

доктор історичних наук, професор, завідувач кафедри готельно-ресторанної та курортної справи, ДВНЗ «Прикарпатський начіональний університет імені Василя Стефаника», вул. Б. Хмельницького, 9, Делятин, Надвірнянський район, ІваноФранківська область, Украӥна, індекс 78442 (volodymyr_klapchuk@ukr.net)

\section{Михайло КЛАПЧУК}

кандидат географічних наук, доиент кафедри туризму Львівського національного університету імені Івана Франка, вул. Ю. Липи, 18, Львів, Україна, індекс 79020 (klapchuk.m@gmail.com)

Бібліографічний опис статті: Klapchuk, V., \& Klapchuk M. (2019). Beer production in Galicia (middle XIXth - the first third of XXth century), Skhidnoievropeiskyi Istorychnyi Visnyk [East European Historical Bulletin], 12, 26-43. doi:10.24919/2519-058x.12.177546

\section{BEER PRODUCTION IN GALICIA (middle XIXth - the first third of XXth century)}

Summary. The purpose of the article is a comprehensive research of beer production in Galicia. Historical approaches to statistical interpretation of events and phenomena, mathematical methods of modeling were used to achieve the goal. The research methodology is an organic set of basic principles of historical research: historicism, objectivity, comprehensiveness, continuity and appropriate methods of scientific research. Various methods of cognition are used in the article: historiographical analysis and synthesis, historical, problem-chronological, statistical, comparative. The scientific novelty lies in the complex analysis of beer production in certain administrative-territorial entities of Austria. Conclusions. In the middle of the XIX century there were over 300 primitive breweries. Until 1856, their number decreased by a third at a stable output. From 1857 to 1865, the number of breweries increased from 263 to 313, and the output increased by 2.8 times. After 10 years, the number of breweries decreased, there has been a tendency towards consolidation of enterprises. From 1876 to 1907, the number of breweries decreased by 2.5 times. In $1885-1900$, beer production has doubled (to 1155 thousand hcl). The growth of taxes was proportional to the output. The beginning of the XX century was marked by the inhibition of the growth of brewery production. In 1901-1907, beer 
production increased by 20\%, taxes - by 38\%. In the 1920's on 41 Galician's brewery were produced more than 100 million liters of beer. Since the mid-1930s, the number of breweries has decreased to 34, a third of which was concentrated in the Lviv voivodship. During the 1930's, breweries produced $500-600$ thousand hcl of various beers annually. Thus, from the middle of the XIX century until the beginning of the Second World War, the number of brewery decreased by 7 times. At the same time, the output of finished products has grown fourfold, the amount of taxes paid - by ten times. The breweries of Galicia had a 10\% of Austria's business enterprises but produced only 5\% of the country's brewing industry. More than 40\% of all Austrian breweries were in the Czech Republic, which produced more than $42 \%$ of products. The share of Galicia in the total amount of Austrian brewery was $4.1-4.3 \%$, and the total amount of beer produced was $4-5.25 \%$. The opposite trend was observed in providing beer per capita. In Galicia, this rate was 0.2 buckets (2.5 liters) per person. For example, in Salzburg, three buckets of beer per one inhabitant, 2-2.5 in the Upper and Lower Austria, 1.6 in the Czech Republic. At the turn of the century, more than 20 million hectares of beer were produced in Austria, of which only $5.75 \%$ in Galicia. This rate was the fourth after the Czech Republic (46.1\%), Lower Austria (18.7\%) and Moravia (10.22\%). The same place Galicia also occupied by the number of breweries. Gross output did not reflect the real state of brewing in the region. The average productivity of the brewery in Galicia was 9.8 thousand hcl, which was one of the lowest indicators in the state. One brewery in Lower Austria produced 59.4, the Austrian Littoral - more than 30.5 thousand hcl of beer. For the production of beer per capita (15 liters) Galicia occupied one of the last places, ahead of only Kraina and the Austrian Littoral. Beer production in Salzburg, the Czech Republic and Lower Austria was highest per capita $(1.21 \mathrm{hcl})$.

Key words: brewery, beer, malt, bucket, hectoliter.

\section{ВИРОБНИЦТВО ПИВА У ГАЛИЧИНІ (середина XIX - перша третина XX ст.)}

Анотація. Метою роботи є комплексне дослідження виробництва пива у Галичині. Для ї̈ досягнення використано загальноісторичні підходи, статистичної інтерпретації подій $i$ явищ, математичні методи моделювання. Методологія дослідження становить органічну сукупність базових принцииів здійснення історичного дослідження: історизму, об'єктивності, всебічності, наступності й відповідних методів наукового пошуку. У статті застосовано різноманітні методи пізнання: історіографічного аналізу та синтезу, історичний, проблемно-хронологічний, статистичний, компаративний. Наукова новизна полягає у комплексному аналізі виробництва пива в окремих адміністративно-територіальних утвореннях Австрії. Висновки. У середині XIX cm. діяло понад 300 примітивних броварень. До 1856 р. ̈̈х кількість зменшилася на третину при стабільному випуску продукиії. 31857 до 1865 рр. кількість броварень зросла з 263 до 313, а випуск продукиії-у 2,8 раза. Через 10 років кількість броварень зменшилась, спостерігалася тенденція до укрупнення підприємств. 31876 до 1907 рр. кількість броварень зменшувалася у 2,5 рази. 1885 - 1900 рр. виробництво пива зросло удвічі (до 1155 тис. гкл). Ріст суми податків відбувався пропориійно до випущеної продукиії. Початок ХХ ст. ознаменувався гальмуванням росту продукиї броварень. У 1901 - 1907 рр. випуск пива зріс на $20 \%$, податки - на $38 \%$. У 1920-х рр. 41 броварнею Галичини продукувалось понад 100 млн. л пива. Від середини 1930-х рр. кількість броварень зменшилася до 34, третина $з$ них зосереджувалася у Львівському воєводстві. Протягом 1930-х рр. броварні щзорічно виробляли 500 - 600 тис. гкл різних сортів пива. Таким чином, від середини ХІХ ст. до початку Другої світової війни число броварень зменшилося усемеро. Водночас, випуск готової продукиії зріс учетверо, сума сплачених податків - у десятки разів. Броварні Галичини, маючи десяту частину підприємств Австрії, виготовляли лише 5 \% продукиї̈ пивоварної промисловості краӥни. Понад $40 \%$ всіх броварень Австрії було у Чехї, яка виробляла понад 42 \% продукиї. Питома вага Галичини у загальній кількості броварень Австрї становила 4,1-4,3 \%, а у загальній кількості виробленого пива - 4-5,25\%. Протилежні тендениії спостерігалися у забезпеченні пивом на душу населення. У Галичині ией показник складав 0,2 відра (2,5 л) на особу. Для прикладу, у Зальибурзі на одного мешкания припадало 3 відра пива, у Верхній та Нижній Австрії-2-2,5, y Чехї- 1,6. На межі століть у Австрії вироблялося понад 20 млн гкл пива, з чого на Галичину 
припадало лиме 5,75\%. Це й показник був четвертим після Чехії (46,1%), Нижсньої Австрії (18,7\%) та Моравї (10,22 \%). Таке ж місие Галичина займала і за кількістю броварень. Валовий випуск продукиї̈ не відображсав реальний стан справ пивоваріння краю. Середня продуктивність броварень Галичини становила 9,8 тис. гкл, щуо було одним з найнижчих показників у державі. Одна броварня Нижньої Австрії виробляла 59,4, Узбережжя - понад 30,5 тис. гкл пива.За виробничтвом пива на душу населення (15 л) Галичина займала одне з останніх місиь, випереджаючи лише Краӥну та Узбережжя. Найбільще на душу населення виробляли пива у Зальибурзі, Чехії та Нижній Австрії (1,21 гкл).

Ключові слова: броварня, пиво, солод, відро, гектолітр.

The problem statement. Nowadays, there is practically no economic history of individual industries and agricultural production. The article provides for the first time a comprehensive analysis of the brewing industry of Galicia from 1847 to the end of the 1930's. The purpose of the article is a comprehensive research of beer production in Galicia. To achieve the goal were used historical approaches to statistical interpretation of events and phenomena, mathematical methods of modeling. The scientific novelty lies in the complex analysis of beer production in certain administrative-territorial entities of Austria.

The source of the research consists of statistical yearbooks, manuals and reference books «Mały rocznik statystyczny» (1930), «Podręcznik Statystyki Galicyi» (1901; 1904; 1908), «Rocznik Statystyki Galicyi» (1887; 1889; 1891; 1893; 1898), «Statystyka przemysłowa» (1935; 1938), «Wiadomości statystyczny o stosunkach krajowych» (1876; 1880). General features of food industry development, including brewing is shown in V. Klapchuk's monography (2015).

Statement of the basic material. Thanks to the Austrian discipline and order, we managed to establish the dynamics of brewing in Galicia. Were established the main indicators of quantity, production and payment of taxes for the years $1847-1907$. The exceptions included the difficult years in political life of the region - 1848 - 1849 (the so-called Spring of Peoples) and 1860 - 1864 (the autonomy of Galicia and its subsequent polonization). These events were obviously more important events than statistics.

Anyway, the analysis showed that in the middle of the XIX century in Galicia there were more than 300 breweries. Most of them were primitive enterprises with small volumes of production and low employment (Fig. 1).

From 1847 to 1856 there was a decrease in the number of enterprises, but an increase in production. During that period, the number of brewery decreased by one third, and output remained the same, with the exception of $1850-1853$, when there was a growth by $20-60 \%$.

From 1857 to 1865 there was a gradual increase in the number of breweries from 263 in 1856 to 313 in 1865. A dramatic increase in output, which began with its increase by $45 \%$ in 1857, peaked in 1865, when it reached 692 thousand hcl of beer, which was 2.8 times higher than in 1856 . Since 1866 the gradual decrease of the number from 313 in 1865 to 101 - in 1907 by three times. At the same time, the output of finished products over the corresponding period increased from 588.5 thousand hcl(1866) to almost 1370 thousand hcl or 2.3 times. We can say that labor productivity has increased seven times. Taking into account the features and sizes of tax legislation, there was a growth of paid taxes proportionally to volumes of finished products. In 1847, more than 240 thousand zlr were paid to the treasury by Galicia's breweries. Then in a quarter century (1871), it exceeded 1 million, in $1899-2$ million, reaching almost 2.6 million zlrin 1907. If in $1847-1857$ breweries paid for 1 hclof beer less than 1 zlr, in 1858 - 1859 - 1,5zlr, then from 1865 to 1907 - already almost 2 zlr.In 1875, the 
number of brewers decreased from 237 in 1873 - 1874 to 230 or $2.95 \%$ in comparison with previous years (this situation lasted from 1865) (Fig. 2; Table 1).

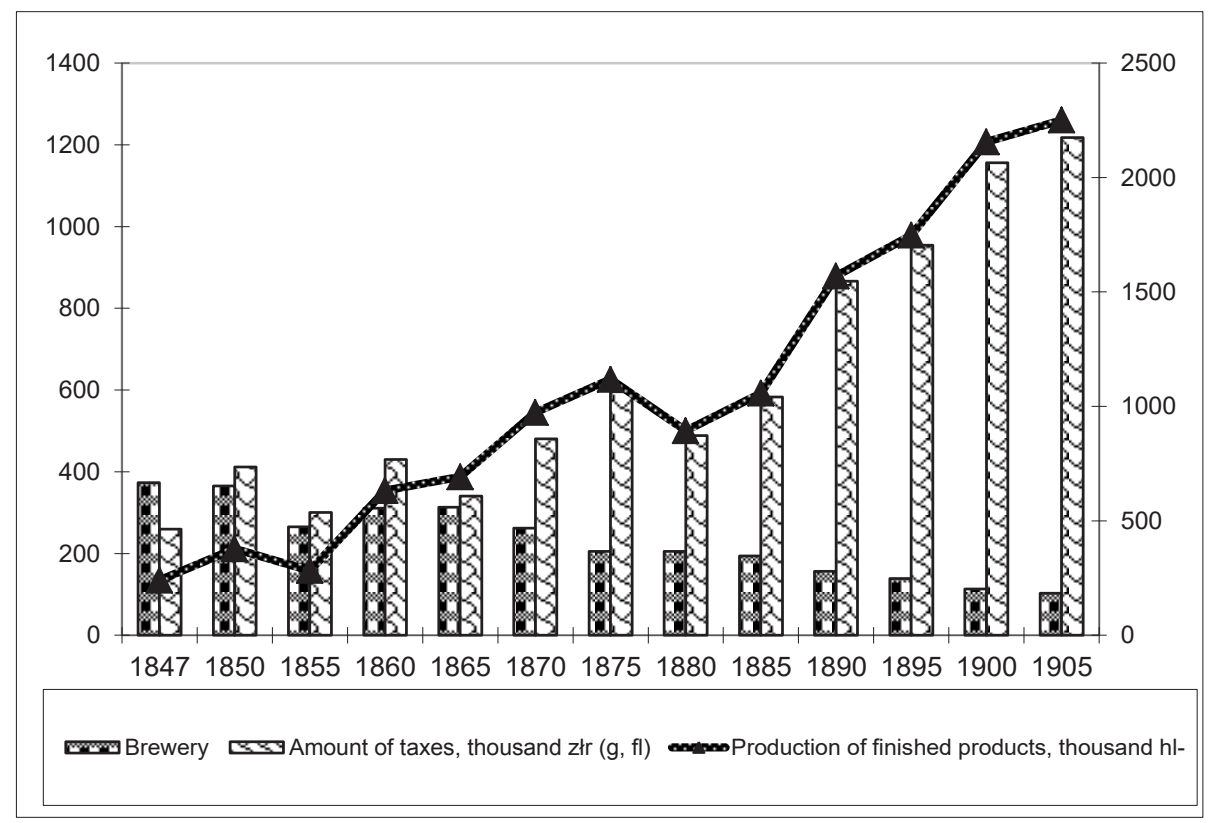

Figure 1. Development of brewing in Galicia, 1847 - 1905 (Pilat T., 1901, p. 224; 1904, p. 201; 1908, p. 234; Rutowski T., 1891, p. 213)

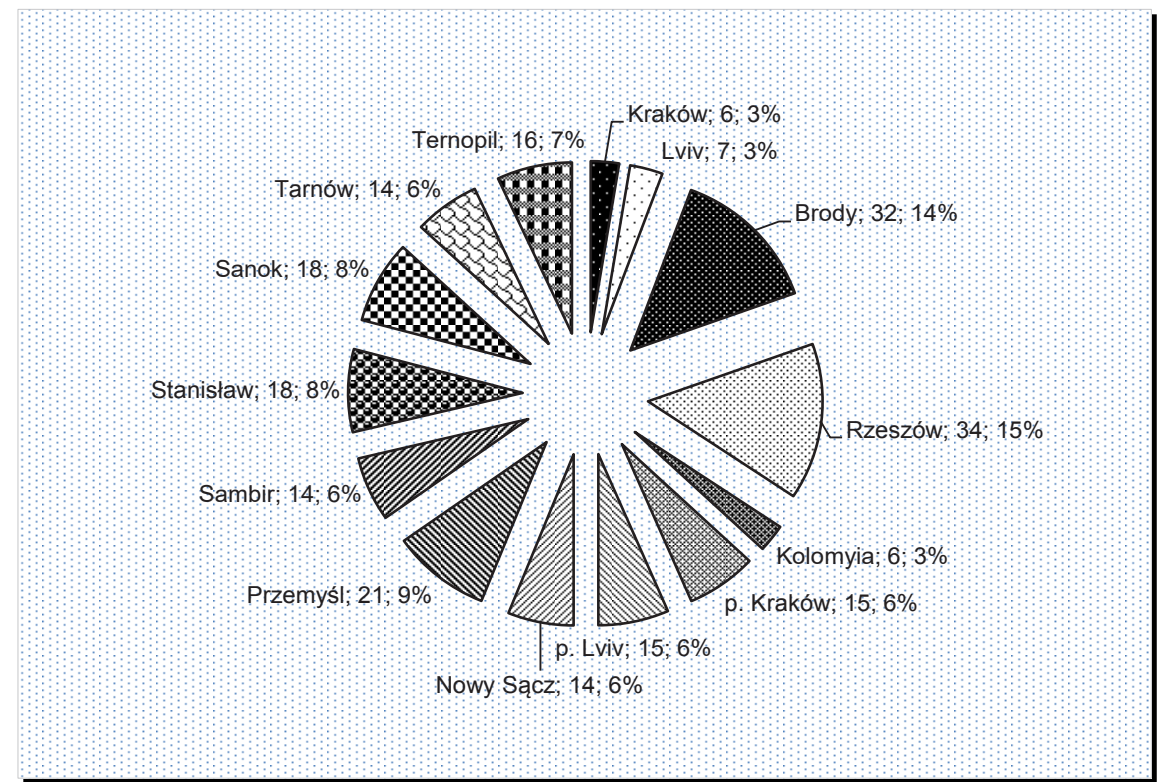

Figure 2. Galicia`s breweries, 1875 (Pilat T., 1876, p. 69) 
The largest number of breweries was in the districts of Rzeszów (34) and Brody (32), the least in the cities of Lviv (7) and Kraków (6), as well as in the Kolomyia district (6). However, half of the breweries in Kraków and 2/3 in Lviv were large enterprises. They paid to the treasury more than 10 thousand zlrannually. Most of the tax districts had more than half of the small breweries, first of all, it concerned the Sanok, Rzeszów, Tarnów disticts (Table 1).

Distribution of brewery in Galicia by the amount of taxes paid and methods of fermentation, 1875 (Pilat T., 1876, p. 69)

\begin{tabular}{|l|c|c|c|c|c|c|c|c|c|c|}
\hline \multirow{2}{*}{ Tax region } & \multicolumn{9}{|c|}{ Amount of taxes, thousands zlr. } & \multicolumn{3}{c|}{$\begin{array}{c}\text { Method of fermentation } \\
\text { on breweries }\end{array}$} \\
\cline { 2 - 14 } & $<1$ & $1-2$ & $2-3$ & $3-4$ & $4-7$ & $7-10$ & $>10$ & Top & Bottom & Both \\
\hline Kraków (city) & 1 & & & & 1 & 1 & 3 & 1 & 4 & 1 \\
\hline Lviv (city) & & & & 1 & & 1 & 5 & & 7 & \\
\hline Brody & 6 & 9 & 7 & & 9 & 1 & & 26 & 5 & 1 \\
\hline Rzeszów & 13 & 11 & 5 & 2 & 2 & 1 & & 21 & 5 & 8 \\
\hline Kolomyia & 1 & & 2 & 1 & 2 & & & 1 & 4 & 1 \\
\hline Kraków & 4 & & 3 & & 4 & 2 & 2 & 3 & 5 & 7 \\
\hline Lviv & 2 & 2 & & 3 & 5 & 2 & 1 & 4 & 9 & 2 \\
\hline NowySącz & 6 & 2 & 2 & & & 3 & 1 & 2 & 11 & 1 \\
\hline Przemyśl & 4 & 7 & 6 & 1 & & & 3 & 16 & 4 & 1 \\
\hline Sambir & 2 & 1 & & & 5 & 2 & 1 & & 10 & 4 \\
\hline Stanisław & 1 & 4 & 4 & 1 & 4 & 1 & 3 & 6 & 10 & 2 \\
\hline Sanok & 10 & 3 & 2 & 1 & 1 & 1 & & 11 & 5 & 2 \\
\hline Tarnów & 8 & 1 & & 1 & & 1 & 3 & 4 & 10 & \\
\hline Ternopil & 1 & 2 & 4 & & 4 & 3 & 2 & 9 & & 7 \\
\hline Galicia & $\mathbf{5 9}$ & $\mathbf{4 2}$ & $\mathbf{3 8}$ & $\mathbf{1 1}$ & $\mathbf{3 7}$ & $\mathbf{1 9}$ & $\mathbf{2 4}$ & $\mathbf{9 1}$ & $\mathbf{1 0 4}$ & $\mathbf{3 5}$ \\
\hline
\end{tabular}

If in $187435.6 \%$ of all brewers paid over $1000 \mathrm{zlr}$ taxes, then in 1875 they remained only $25.63 \%$. At the same time, the number of those brewers who paid annually more than 10 thousand zlr (10.43\% versus 6.8\%) increased. In 1875, there were 11 entrepreneurs in Galicia, who produced over 15 thousand buckets of beerannually. Thus, there was a tendency for the consolidation of enterprises that displaced small unprofitable breweries (Pilat, 1876, p. 70).

Beer production in Galicia increased significantly in comparison with the last years.It was almost 13.75 million liters in 1875 (Fig. 3).

Compared to 1874 , this difference was $17.5 \%$. The largest beer production was made by brewers in Krakow and Lviv, Tarnów and Brody districts. The smallest beer production was in Kolomyia (1.8\%) and Sanok (2.67\%). The annual distribution of paid taxes was directly proportional to the number of products produced. However, there were certain conflicts related in some districts to the difference in tax rates (Fig. 4). Thus, Lviv, produced $11.16 \%$ of all beer production in Galicia and paid $12.5 \%$ of taxes to the treasury. A similar situation was observed in Stanisław, Tarnów and Ternopil, and other districts. Significantly fewer percentages were paid by the districts of Brody, Rzeszów, Sanok, etc., where small breweries were predominant. These breweries produced beer using the top fermentation method. 


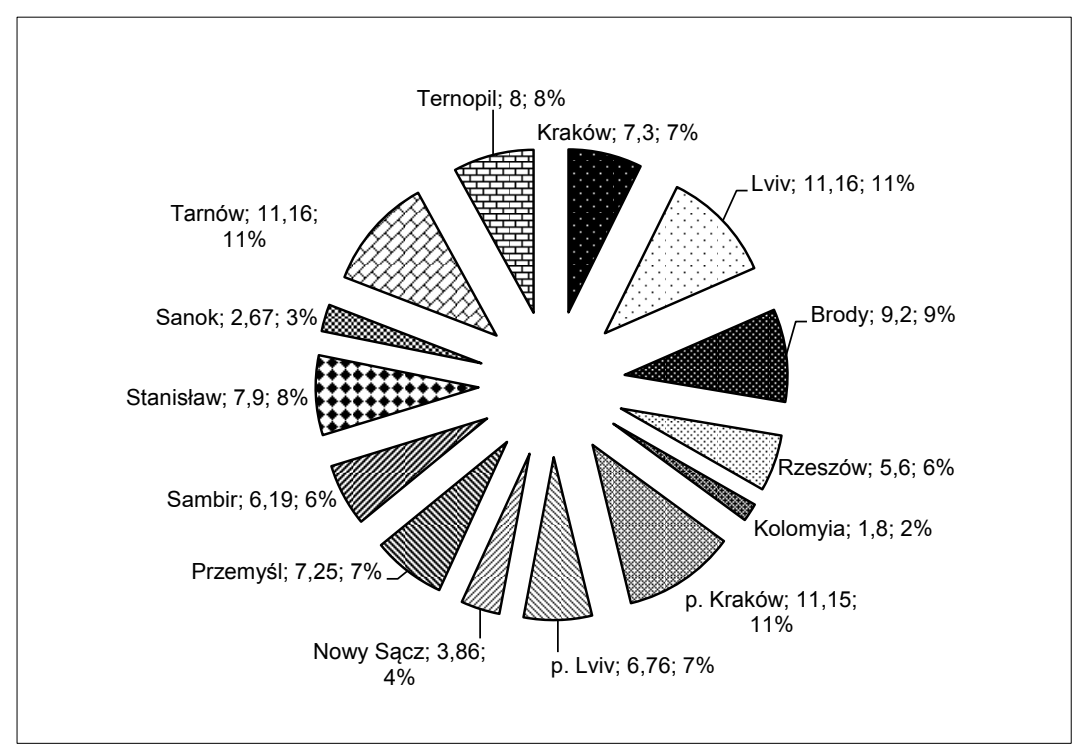

Figure 3. Production of beer by Galicia's brewery (\%), 1875 (Pilat, 1876, p. 70)

The largest number of brewery products was produced in Lviv, where on average about 235.5 thousand liters were sold per brewery. In Kraków were almost 150 thousand liters (Pilat, 1876, p. 73). Most volume of the beer per capita was produced in the cities of Lviv and Kraków, and among the districts - in Tarnów, Kraków and Brody. Generally, in Galicia, was produced about 2.5 liters of beerper capita.

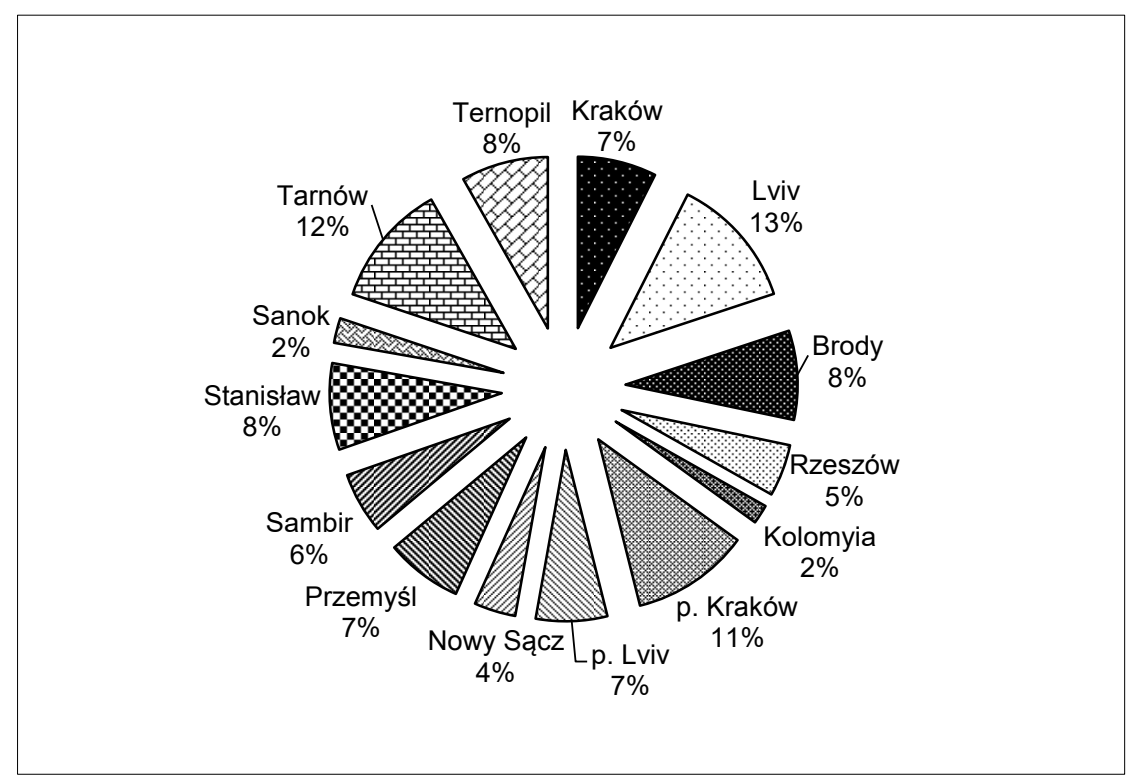

Figure 4. Payment of taxes by Galicia's brewery, 1875 (Pilat, 1876, pp. 71-72) 
The breweries of Galicia, having a tenth of the enterprises, produced only more than $5 \%$ of the Austrian brewery production. More than $40 \%$ of all Austrian breweries were in the Czech Republic, which produced more than $42 \%$ of the products of Predlitavia.

In general, in Austria there was a slight decrease in the number of breweries, first of all, in the Czech Republic, Galicia and Bukovyna. In Lower Austria, Salzburg, the Kraina and the Austrian Littoral the number remained unchanged, and in the rest of the districts - increased. The share of Galicia in the total number of Austro-Hungarian brewers decreased from $4.32 \%$ in 1874 to $4.12 \%$ in 1875 (Fig. 5).

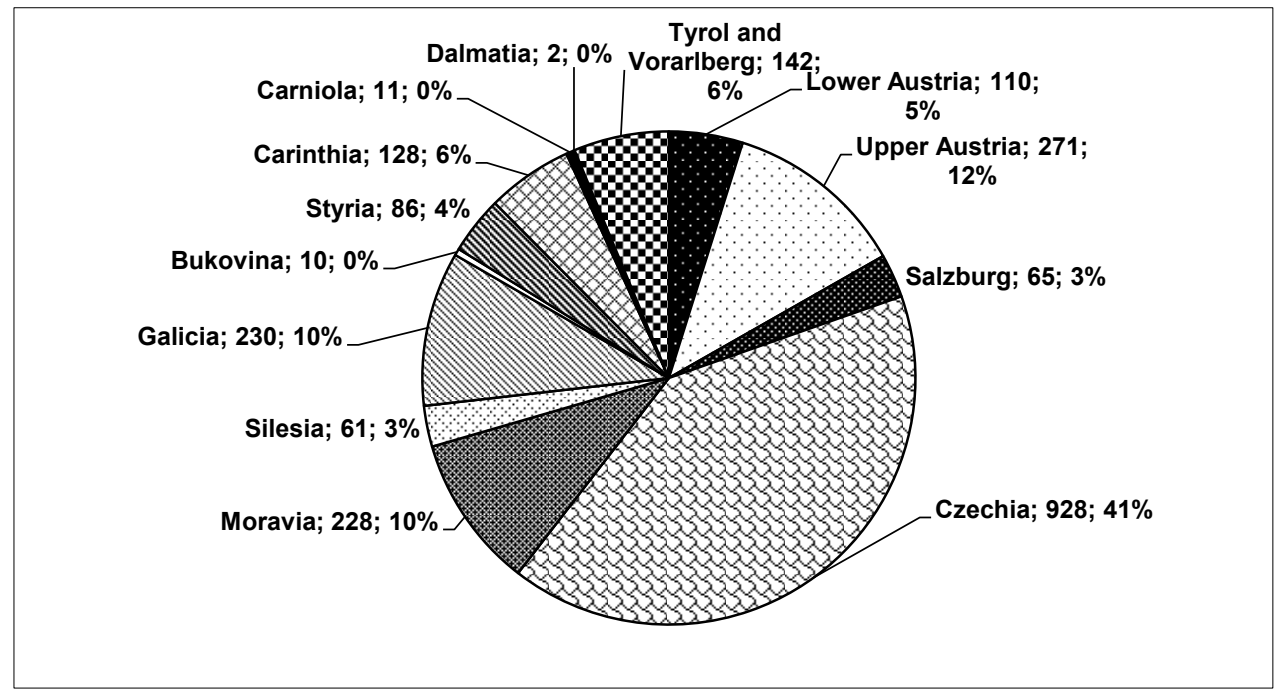

Figure 5. Number of breweries in Austria, 1875 (Pilat, 1876, p. 73-74)

The number of manufactured products of both Austro-Hungary and most of the districts also decreased - by almost 370 thousand buckets. The only exception was Galicia, whose production increased significantly. As we wrote, the share of Galicia in the total amount of beer produced in Austria-Hungary increased from $4.02 \%$ in 1874 to $5.25 \%$ in 1875 . Despite the fact that Galicia was the fifth producer of beer in Austria, it still produced over 120 thousand bucks more than Hungary (Fig. 6).

The opposite trend was observed in providing beer to the population (Fig. 7). Salzburg had 3 buckets of beer per inhabitant, 2-2.5 in the Upper and Lower Austria and 1.6 in Czech Republic, in Galicia this rate was only 0.2. By this indicator, Galicia outpaced only the following regions of Austria-Hungary, such as Bukovyna, Kraina and Austrian Littoral (Pilat, 1876, pp. 93-95).

Depending on the fermentation method, the prices for beer ranged from 4.4 zlr per bucket in Brody's to 5.3 in Lviv's and 6 in Krakow's chambers of commerce and industry (Fig. 8). In general, Galicia produced in 1875 beer for almost 6 million zlr.

During 1875-1878, the situation with the brewing industry changed a little. The number of breweries declined both in absolute terms (with the exception of $1875-1876$ ), and by the number of enterprises that paid taxes of more than 10 thousand zlr (Pilat, 1880, p. 205). The number of breweries, that used upper fermentation method for the beer production decreased (Table 2). 


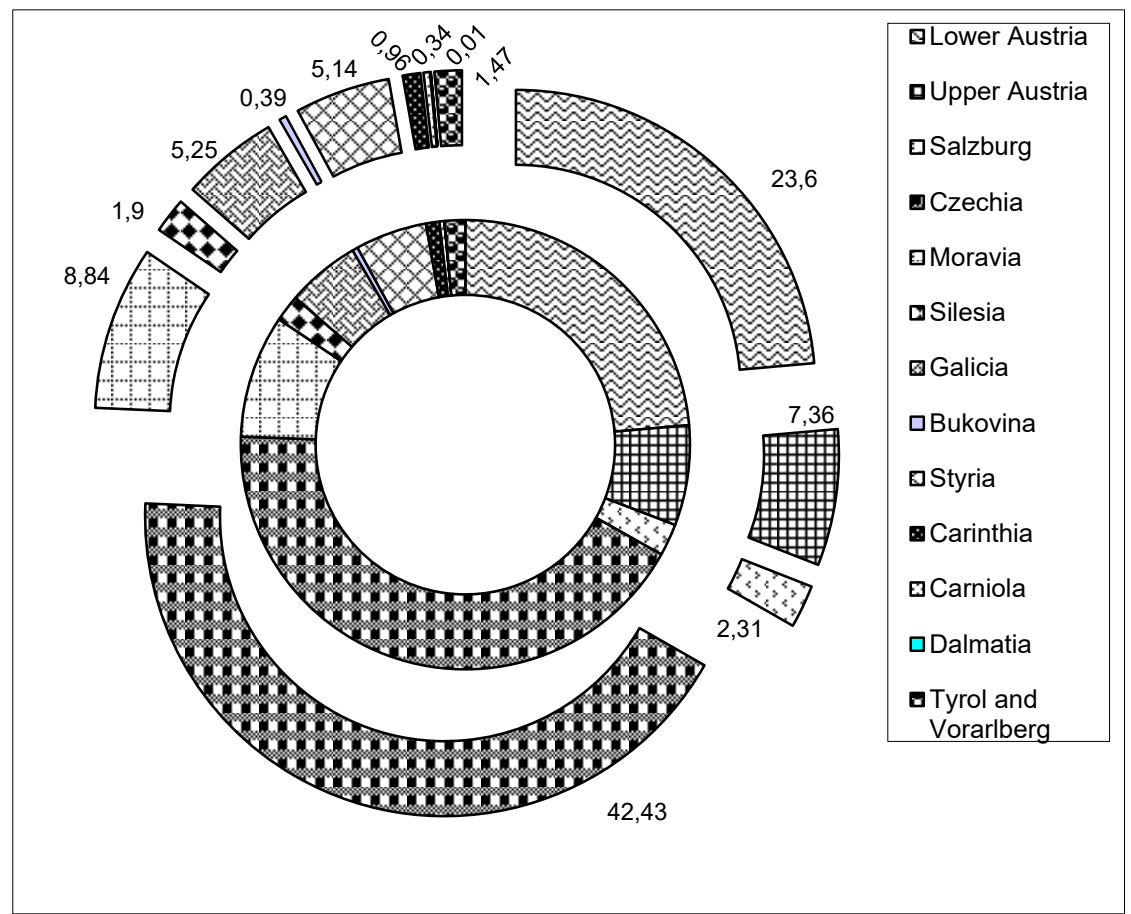

Figure 6. Beer production in Austria (1874 - 1875) (Pilat T., 1876, p. 93-95)

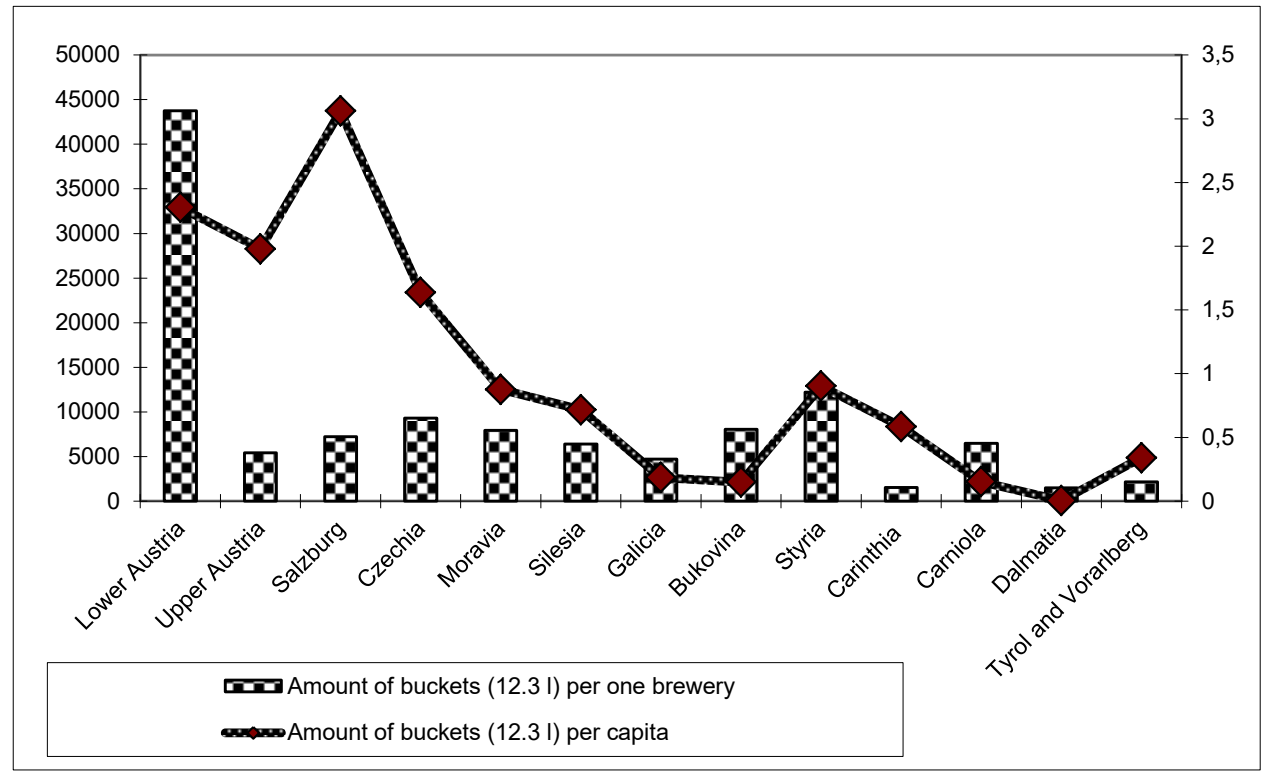

Figure 7.Producing of beer per one brewery and per capita in Austria, 1875 (Pilat, 1876, p. 95) 


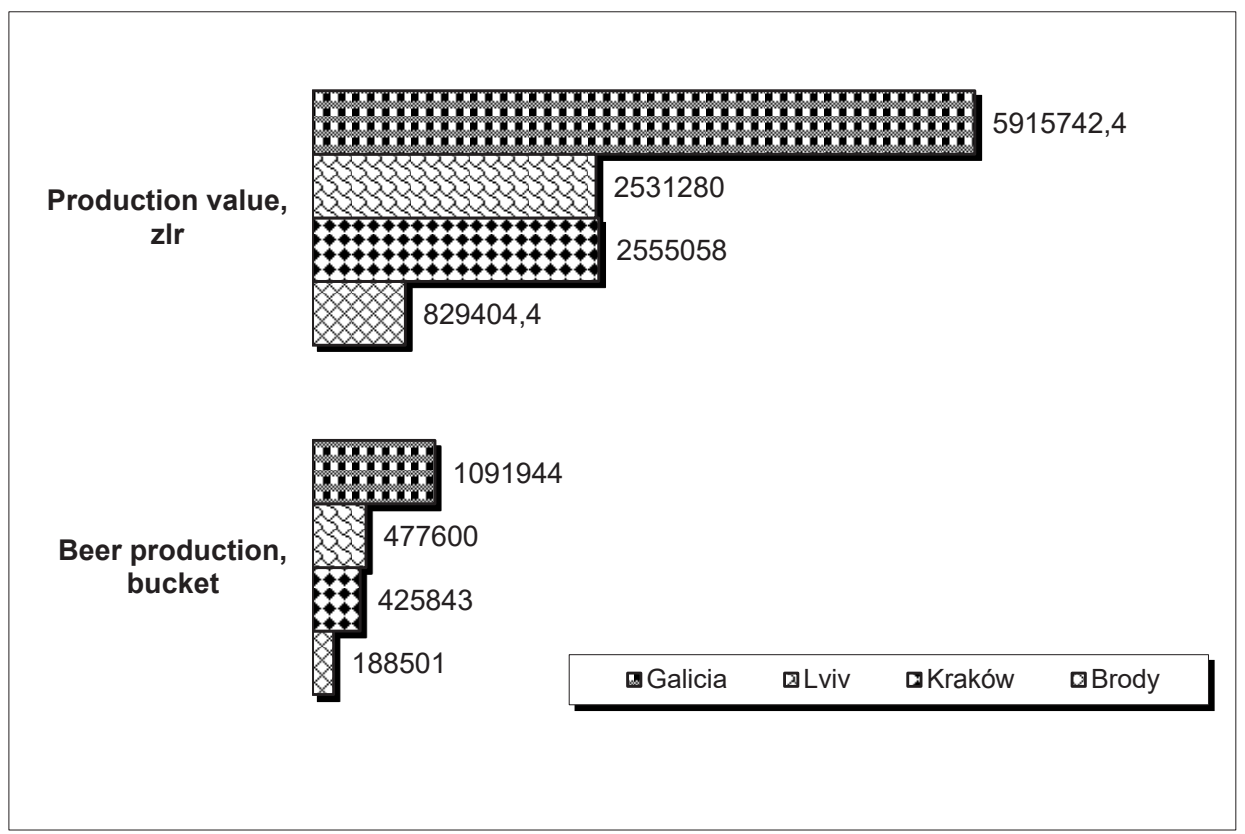

Figure 8. Issue and cost of brewery production in Galicia in the context of chambers of commerce and industry, 1875 (Pilat, 1876, p. 76, 94)

By 1878, the number of breweries decreased in almost all districts, except for the city of Lviv and the district of Rzeszów. The biggest number of breweries (since the early 1870's) were in Brody, Rzeszów, Peremyshlyany and Ternopil districts, the smallest number - in the cities of Kraków and Lviv, as well as in the Kolomyia district.

From all breweries in the campaign of 1877 - 1878 worked with a tax payment of less than $1,000 \mathrm{zlr}$ about $31 \%$ of enterprises, from 1 to 4 thousand $-43 \%$, from 4 to 10 thousand $-19 \%$ and more than 10 thousand zlr $-7 \%$. For three years, the number of small breweries has increased (Fig. 9). Almost by 5\% increased the number of breweries who paid less than 1 thousandzlr, by $4 \%$ - from 1 to 4 thousand zlr. Instead this decreased number of breweries that paid 4-10 thousand (by 5\%) and more than 10 thousand (by 3.7\%) zlr (Pilat, 1880, pp. 195-196).

As already noted, the number of breweries that used top fermentation method of brewering decreased and of the ones that usedbottomfermentation method increased (Fig. 10). The sustainable growth of beer production that usedbottom fermentation method was due to the fact that this beer was better and stronger.

The seasonal dynamics of Galicia's brewery has shown that the largest number of breweries (93-95\%) worked:

- 1876 - February-March, less - December-January;

- 1877 - February-March, less - November-December;

- 1878 - January-March, less - December, April. 
Table 2

Payment of taxes by Galician breweries in 1875 - 1878 (Pilat T., 1880, p. 205)

\begin{tabular}{|c|c|c|c|c|c|c|c|c|c|c|}
\hline \multirow{3}{*}{ Tax region } & \multirow{3}{*}{ Action } & \multicolumn{2}{|c|}{ Breweries } & \multicolumn{7}{|c|}{ Amount of taxes, thousands zlr. } \\
\hline & & \multirow{2}{*}{ Number } & \multirow{2}{*}{$\%$} & $<1$ & $1-2$ & $2-3$ & $3-4$ & $4-7$ & $7-10$ & $>10$ \\
\hline & & & & \multicolumn{7}{|c|}{ Number of breweries } \\
\hline \multirow{3}{*}{ Kraków (city) } & $1875-1876$ & 6 & 2,55 & 1 & 0 & 0 & 1 & 1 & 0 & 3 \\
\hline & $1876-1877$ & 5 & 2,17 & 0 & 0 & 1 & 0 & 0 & 2 & 2 \\
\hline & $1877-1878$ & 4 & 1,79 & 0 & 0 & 0 & 0 & 0 & 2 & 2 \\
\hline \multirow{3}{*}{ Lviv (city) } & $1875-1876$ & 7 & 2,98 & 1 & 0 & 1 & 0 & 1 & 0 & 4 \\
\hline & $1876-1877$ & 6 & 2,61 & 0 & 0 & 0 & 1 & 1 & 0 & 4 \\
\hline & $1877-1878$ & 7 & 3,13 & 0 & 1 & 0 & 1 & 1 & 0 & 4 \\
\hline \multirow{3}{*}{ Brody } & $1875-1876$ & 32 & 13,62 & 6 & 9 & 6 & 1 & 9 & 1 & 0 \\
\hline & $1876-1877$ & 30 & 13,04 & 7 & 5 & 6 & 4 & 6 & 1 & 1 \\
\hline & $1877-1878$ & 31 & 13,84 & 9 & 5 & 6 & 6 & 3 & 2 & 0 \\
\hline \multirow{3}{*}{ Rzeszów } & $1875-1876$ & 32 & 13,62 & 12 & 9 & 5 & 3 & 2 & 1 & 0 \\
\hline & $1876-1877$ & 33 & 14,35 & 15 & 8 & 6 & 2 & 1 & 1 & 0 \\
\hline & $1877-1878$ & 33 & 14,73 & 16 & 10 & 3 & 3 & 0 & 1 & 0 \\
\hline \multirow{3}{*}{ Kolomyia } & $1875-1876$ & 6 & 2,55 & 1 & 1 & 2 & 0 & 2 & 0 & 0 \\
\hline & $1876-1877$ & 6 & 2,61 & 1 & 2 & 1 & 0 & 2 & 0 & 0 \\
\hline & $1877-1878$ & 5 & 2,23 & 0 & 1 & 1 & 1 & 2 & 0 & 0 \\
\hline \multirow{3}{*}{ Kraków } & $1875-1876$ & 15 & 6,38 & 3 & 1 & 1 & 1 & 5 & 1 & 3 \\
\hline & $1876-1877$ & 15 & 6,52 & 4 & 0 & 2 & 2 & 3 & 1 & 3 \\
\hline & $1877-1878$ & 15 & 6,70 & 3 & 3 & 1 & 2 & 3 & 1 & 2 \\
\hline \multirow{3}{*}{ Lviv } & $1875-1876$ & 16 & 6,82 & 2 & 2 & 2 & 3 & 4 & 2 & 1 \\
\hline & $1876-1877$ & 17 & 7,39 & 4 & 2 & 4 & 2 & 3 & 1 & 1 \\
\hline & $1877-1878$ & 16 & 7,14 & & & & & & & \\
\hline \multirow{3}{*}{ NowySącz } & $1875-1876$ & 14 & 5,96 & 5 & 1 & 2 & 2 & 1 & 2 & 1 \\
\hline & $1876-1877$ & 13 & 5,65 & 5 & 1 & 2 & 0 & 3 & 1 & 1 \\
\hline & $1877-1878$ & 13 & 5,80 & 4 & 1 & 2 & 0 & 4 & 2 & 0 \\
\hline \multirow{3}{*}{ Przemyśl } & $1875-1876$ & 23 & 9,79 & 6 & 3 & 9 & 2 & 0 & 1 & 2 \\
\hline & $1876-1877$ & 22 & 9,57 & 6 & 6 & 7 & 0 & 0 & 1 & 2 \\
\hline & $1877-1878$ & 20 & 8,93 & 7 & 9 & 1 & 0 & 0 & 1 & 2 \\
\hline \multirow{3}{*}{ Sambir } & $1875-1876$ & 15 & 6,38 & 1 & 0 & 4 & 2 & 5 & 2 & 1 \\
\hline & $1876-1877$ & 14 & 6,09 & 2 & 1 & 1 & 4 & 3 & 2 & 1 \\
\hline & $1877-1878$ & 13 & 5,80 & 1 & 4 & 1 & 2 & 3 & 1 & 1 \\
\hline \multirow{3}{*}{ Stanisław } & $1875-1876$ & 19 & 8,08 & 2 & 4 & 4 & 1 & 5 & 0 & 3 \\
\hline & $1876-1877$ & 18 & 7,83 & 4 & 3 & 2 & 2 & 4 & 1 & 2 \\
\hline & $1877-1878$ & 17 & 7,59 & 7 & 2 & 1 & 2 & 2 & 2 & 1 \\
\hline \multirow{3}{*}{ Sanok } & $1875-1876$ & 17 & 7,23 & 10 & 2 & 2 & 0 & 3 & 0 & 0 \\
\hline & $1876-1877$ & 16 & 6,96 & 7 & 3 & 3 & 1 & 1 & 1 & 0 \\
\hline & $1877-1878$ & 16 & 7,14 & 8 & 4 & 1 & 1 & 2 & 0 & 0 \\
\hline \multirow[t]{3}{*}{ Tarnów } & $1875-1876$ & 14 & 5,96 & 6 & 3 & 0 & 1 & 1 & 0 & 3 \\
\hline & $1876-1877$ & 13 & 5,65 & 6 & 2 & 0 & 0 & 2 & 0 & 3 \\
\hline & $1877-1878$ & 13 & 5,80 & 7 & 1 & 0 & 1 & 1 & 2 & 1 \\
\hline Ternopil & $1875-1876$ & 19 & 8,08 & 1 & 4 & 5 & 1 & 5 & 0 & 3 \\
\hline & $1876-1877$ & 22 & 9,56 & 2 & 6 & 5 & 3 & 2 & 1 & 3 \\
\hline & $1877-1878$ & 21 & 9,38 & 3 & 7 & 4 & 3 & 1 & 1 & 2 \\
\hline & $1875-1876$ & 235 & 100 & 57 & 39 & 43 & 18 & 44 & 10 & 24 \\
\hline Galicia & 1876-1877 & 230 & 100 & 63 & 39 & 40 & 21 & 31 & 13 & 23 \\
\hline & $1877-1878$ & 224 & 100 & 69 & 52 & 23 & 22 & 26 & 17 & 15 \\
\hline
\end{tabular}




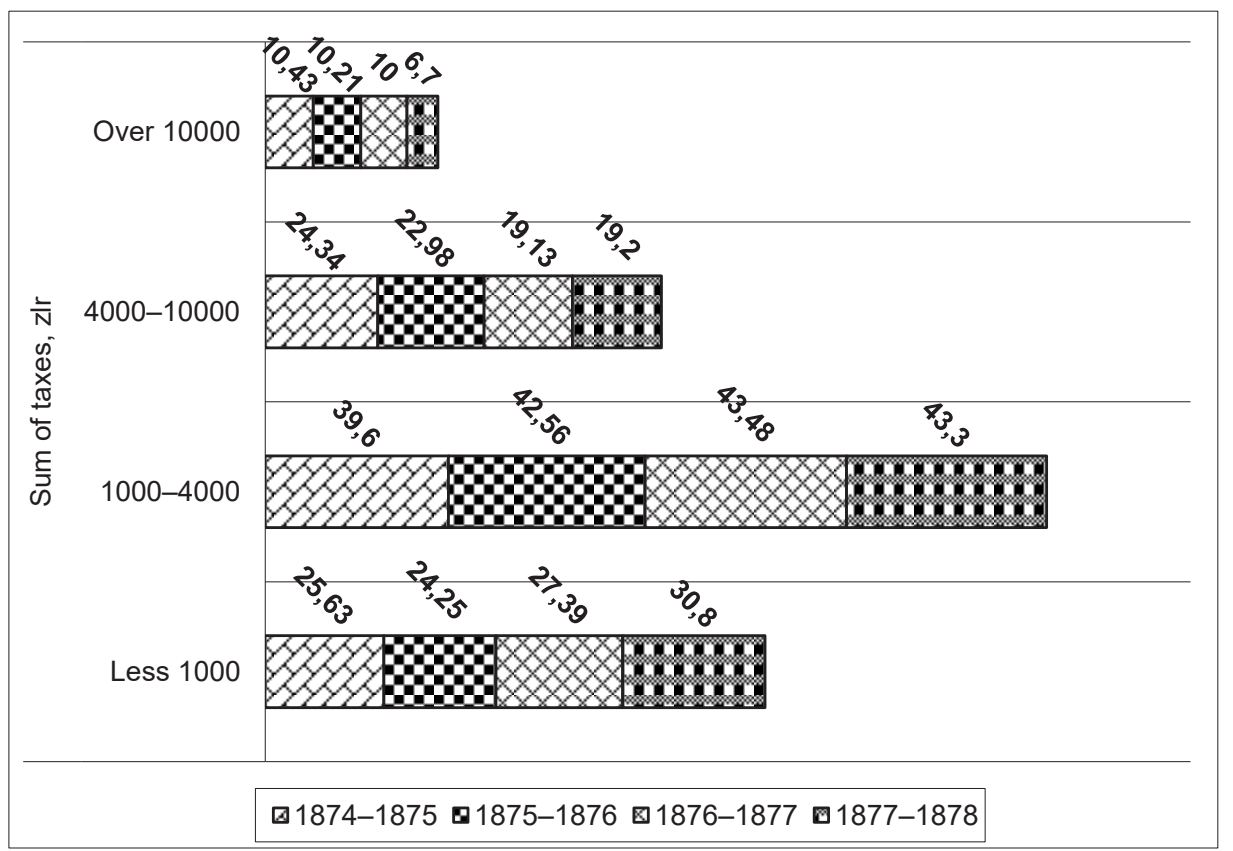

Figure 9. Classification of Galician breweries by size of taxes (Pilat, 1880, pp. 195-196)

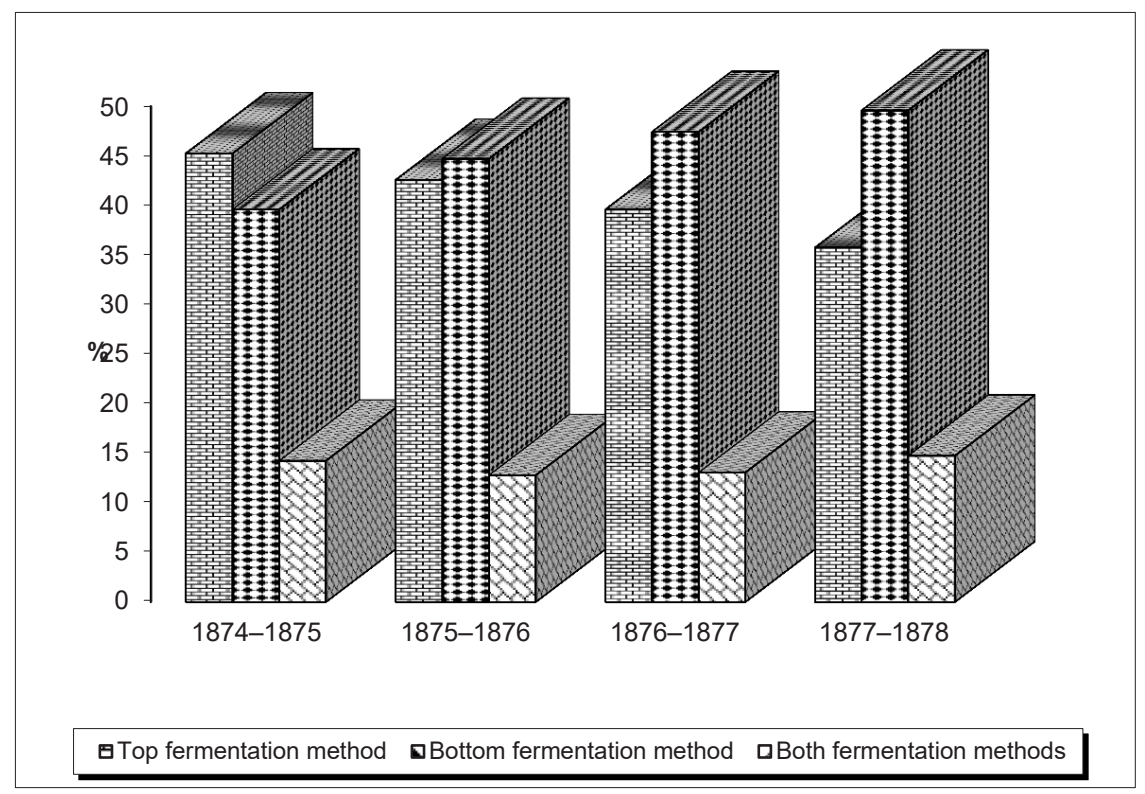

Figure 10. Classification of breweries by methods of fermentation (Pilat, 1880, p. 197) 
With a decrease in the number of breweries, there was a decrease in the production of beer. In 187561793101 of beerwere produced (Fig. 11). In 1876 - 5958530 l, in 1877 50782801 , in $1878-50202401$. However, it should be noted that in 1874 were produced 5067640 liters, which practically equaled to $1877-1878$. Reduction of beer production was due to the production of a smaller number of higher grades of products. 9-10-degree beer was prodused a little lessthan before 1875, 11-12-degree - as in the previous period, but the beer brand in 13 degrees was made much less $(1875-109883 \mathrm{hcl}, 1876-72197 \mathrm{hcl}$, $1877-39768 \mathrm{hcl}, 1878$ - $15671 \mathrm{hcl})$. A 14-degree beer were produced little - only $114 \mathrm{hcl}$ in $1878(1876-4306 \mathrm{hcl})$. Average strength of beer decreased with each year: $1874-11,5^{\circ}$; $1875-11,3^{\circ} ; 1876-11,2^{\circ} ; 1877-11,18^{\circ} ; 1878-11.07^{\circ}$ (Pilat, 1880, p. 197).

In 1878 , in comparison with 1876 , the production of beer was generally lower in almost half of tax districts, with the exception of Brody, Kolomyia, Przemyśl, Stanisław and Lviv districts (southeastern Galicia). Steady leaders of beer production (Krakówand Tarnów districts) slowly lost their positions. In 1878,Lviv and Brody districts overtook them in terms of beer production. The smallest beer production was further by Kolomyia and Sanok districts.

In parallel with the reduction of production output, there was a decrease in the amount of taxes from 1117653 zlr in 1876 to 948791 in 1877 and 929014 in 1878 (Pilat, 1880, pp. 217-219). However, in some districts there were certain exceptions of the rules. Thus, in Lviv and Tarnówdistricts, the percentage of taxes paid was higher than the percentage of production. At the same time, it was lower in Brody, Rzeszów and Sambir districts. This was due to the fact that breweries in Lviv and Tarnów districts produced beer of higher strength, for which higher tax rates were paid.

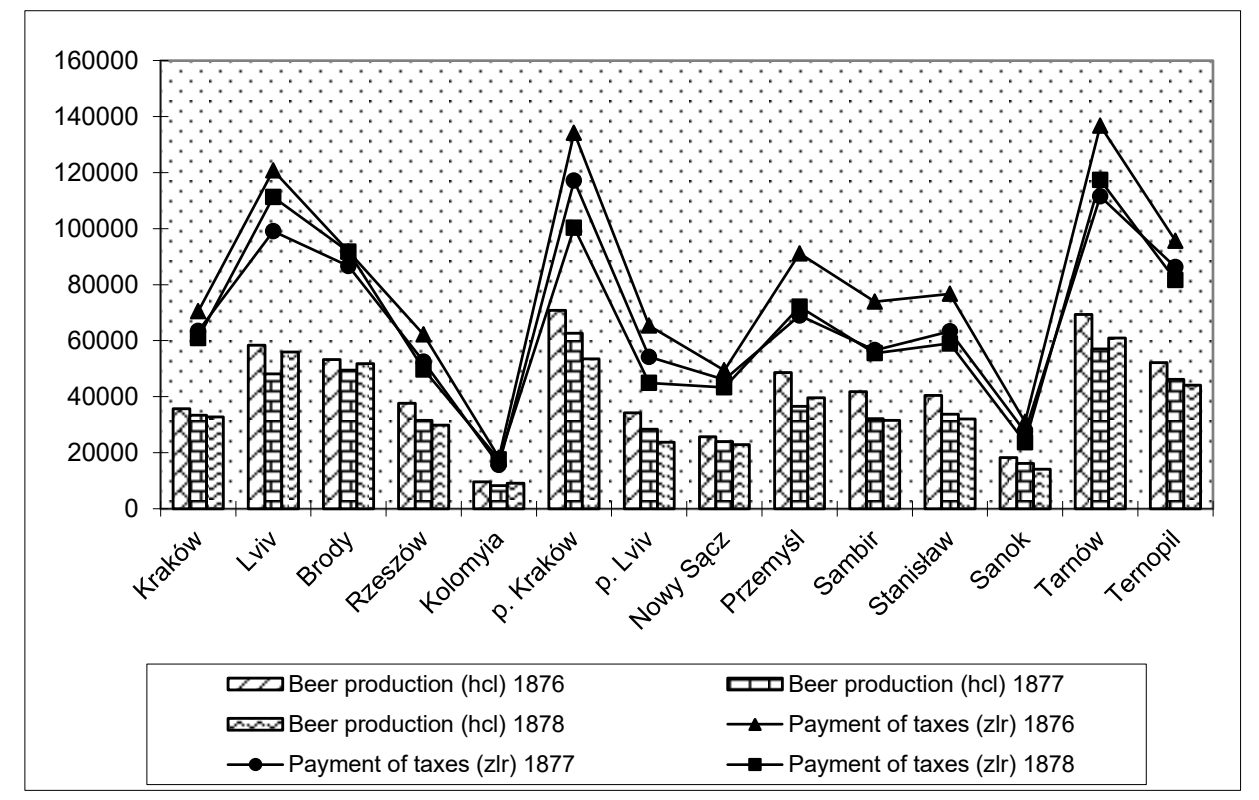

Figure 11. Production of beer and payment of taxes by Galicia's brewery in the context of tax districts (Pilat, 1880, p. 214-216) 
During 1875 - 1876 the largest beer producerwas the city of Lviv (7680 hcl). In 1877 , the breweriesof Krakow produced more beer $(7810 \mathrm{hcl})$. From the suburban tax districts, the biggest volume of beer production,per one brewery, were in Krakówand Tarnów districts. The smallest were in Rzeszów and Sanok districts.

In Kraków and Lviv cities districts were produced the biggest volume of beer per capita (approximately $60 \mathrm{l}$ / person). In Tarnów it was 12-14 1/ person, Brody - 11-12 1/ person and Kraków suburban - 11-15 1/ person. The smallest volumes of beer production, per capita, were in Kolomyia (up to 2 1/ person), Sanok (3-4 1/ person) and Nowy Sącz (5-6 1/ person) districts.

In general, in Galicia, on average, one brewery produced 218-256 lbeer per year, which per capita was in the range of 8.4-10.6 liters (Pilat T., 1880, p. 220).

The lowest prices were recorded in the Brody chamber of commerce and industry (8.5-9 zlr per $1 \mathrm{hcl}$ of beer), the highest in Lviv (9.5-10.2). It should be noted that the price for beer in the city of Lviv was 2-2.5 zlr cheaper than outside the city district. The least variations of prices for beer were observed in the territory of Kraków (9.16-9.32 zlr) and Brody ( $8.5-9$ zlr) chambers of commerce and industry. InLvivchamber of commerce and industry there was a steady fall in prices from 10.17 to $9.48 \mathrm{zlr}$. There was also a decreased in the total cost of beer production in Galicia from 5.67 to 4.6 million zlr. Reduce of beer production in Galicia has led to a decrease in total income by almost $20 \%$ or by 1 million zlr (Pilat, 1880, s. 224). In 1876, the income of the breweries after paying taxes was 4550 thousand zlr,in 1877 - 3826thousand zlr,in 1878 - 3703 thousand zlr.

From 1876 to 1907 , in certain tax districts of Galicia, there was a diametrically opposite situation with the number of breweries: in some of them there were over 40 , in others - less than 5. However, the trend was the same for all districts - the number of breweries has steadily decreased, reaching a 30-year fall by 2.5 times (Pilat, 1901, p. 224, 1904, p. 203, 1908, p. 234, Rutowski, 1887, p. 187).

During that period of 1876 - 1907 there were less than ten breweries in districts: the city of Kraków, the city of Lviv, Berezhany, Zhovkva, Kolomyia, Chortkiv. In Brody and Ternopil districts, the number of brewery has never been less than ten. The largest decrease in the number of enterprises was observed in Rzeszów (from 33 to 9) and Brody (from 30 to 11) tax districts. Absolute maximum (44 breweries) was recorded in Rzeszów districtin 1884.

From 1885 to 1900, the production of beer in Galicia doubled - from 582 to 1155 thousand hcl; in Kolomyia district - by 4.7 times, in Lviv and Wadowicedistricts - 3.5-3.7 times, in Jarosław and Tarnówdistricts, three times (Fig. 12) (Pilat T., 1901, p. 225-227; 1904, p. 202, Rutowski T., 1889 , p. 202, 1891, p. 214, 1893, p. 282, 1898, p. 253-256). Only in Kraków and Sambir districts the output decreased by 50 and 3\%, respectively. The total volume of released products grew by 40-60 thousand hclannually.

The beginning of the XX century was marked by the inhibition of the growth of beer production (Fig. 12). Between 1901 and 1907, beer production increased by only $20 \%$, and in some years $(1902,1907)$ there was a decrease compared with the previous years $(1903$, 1906, respectively).

In different tax districts, the situation was different: in some districts, the production of beer decreased (Kraków, Zhovkva, Chortkiv), in others - increased. Significant growth (more than 30\%) was recorded in Lviv, Brody, Kolomyia, Kraków and Tarnów districts. 


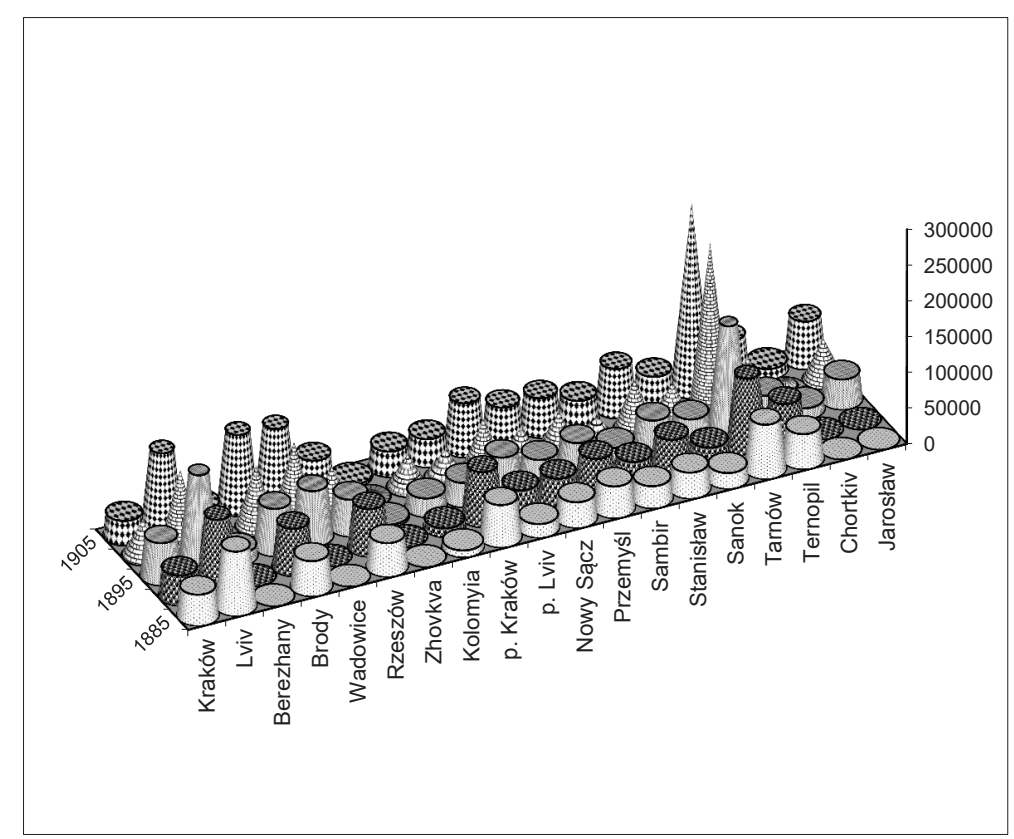

Figure 12. Beer production in tax districts of Galicia, 1885 - 1905, hcl (Pilat, 1901, p. 225-227; 1904, p. 202, Rutowski, 1889, p. 202, 1891, p. 214, 1893, p. 282, 1898, p. 253-256)

In accordance with volumes of released products, features of quality and grades of beer, tax laws in the years 1885 - 1900 there were next tax payments shown in fig. 13. In general, in Galicia, not pay attention on 1885 , which was exceptional in the financial system of the region, the growth of taxes was in parallel with the output. During the relevant period, the amount increased from almost 1250 to 2,155 thousand zlr or $72.5 \%$. If we compare that the output of breweries has doubled in that period, there were certain tax breaks for beer producers. The largest taxes were paid in Tarnów (20\% of Galicia), the city of Lviv (10\%) and Wadowice (9\%); the smallest - Zhovkva (0.3\%) and Chortkiv (1\%).

In the following years $(1900-1905)$, the same trends and features of taxation took place, so the picture of leaders and outsiders did not change (see Fig. 13). The growth of taxes in the province grew from 2131.4 thousand zlr to 2937.4 thousand zlr or $38 \%$. It should be noted that the output for the relevant period increased by only $20 \%$. However, you should not think that tax pressure on beer producersincreased. More likely, this was due to inflationary processes in the first decade of the XX century. The share of the largest beer producer in Galicia Tarnówdistrict, was still the fifth. Somewhat decreased the share of Lviv city district $(7.5 \%)$ and remained unchanged Wadowice district (9\%). Chortkiv and Zhovkva together produced less than $1 \%$ of the total output of Galicia.

At the turn of the century, more than 20 million hcl of beer were produced in 1423 breweries in Austria (Fig. 14), from which Galicia accounted for only 5.75\% (1.15 million liters). This rate was the fourth after the Czech Republic (46.1\%), Lower Austria (18.7\%) and Moravia $(10.22 \%)$. The same place Galicia also occupied by the number of breweries. But the gross output did not characterize the real situation in the brewing region, because the average 
productivity of the Galician brewery was much lower than the other teritories of the state. Thus, one brewery in Lower Austria accounted for more than 59.4 thousand hcl of beer, more than 30.5 thousand hcl in Austrian Littoral, Styria - 21.3thousand hcl, Moravia 16.3thousand hcl, Bukovyna - 15.7thousand hcl, the Czech Republic - 14.2 thousand hcl, Silesia - 12.6thousand hcl, then in Galicia - about 9.85 thousand hcl, which was the eight result of 14 regions of Austria (Pilat, 1904, p. 201).

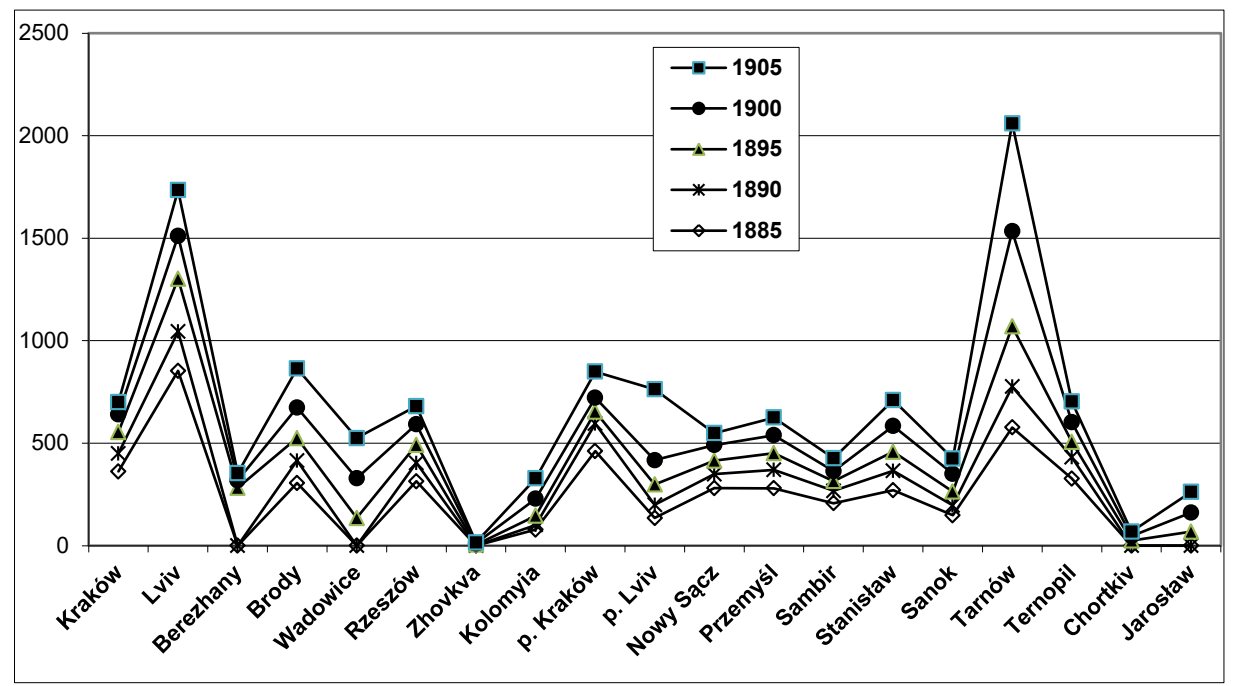

Figure 13. Tax payment by Galician brewery in the context of tax districts, zlr

For production of beer per capita Galicia took one of the last places (15 1/ person), ahead of only the Kraina and the Austrian Littoral. Beer production in Salzburg ( $2.83 \mathrm{hcl} /$ person), Czech Republic (1.46 hcl / person) and Lower Austria (1.21 g/ person) were the highest per capita.

It should also be noted that Galicia produced per capita 7.7 liters of alcohol and only 15 liters of beer.

In the 1920's, there was a small amount of industrial breweries in Galicia (1928 - 41, 2054 workers), which produced over 100 million liters of beer. These plants operated power systems with a total capacity of over $8300 \mathrm{hp}$ (Mały rocznik statystyczny, 1930, p. 47).

In the mid-1930's, the number of brewery in Galicia continued to decrease, reaching only 34 enterprisesin 1937, more than a third of them concentrated in the Lvivvoivodship. In Krakówvoivodship, during the years of 1933 - 1937, there were 8-10 breweries. In Lvivat the same time there were 12-13. In Stanislaviv - 5, and Ternopil - 9-11. The brewery generally employed 1,600 people, each of which had 43 people. The largest number of employees, indicating the size of brewing enterprises, was in the Krakówvoivodship, where more than 110 people worked on average in each enterprise (Statystyka przemysłowa, 1935, p. 44-50, 1938, p. 58-68).

$94 \%$ of brewery workers were men. The rest were women and, in single cases, boys and girls.

During the 1930's, breweries and other enterprises of Galicia produced from 630 (in 1937) to 750 (in 1931) thousand hcl of beer and malt. $80 \%$ of that production were various sorts of beer (Fig. 15). There was an annual decline in production of beer and malt, which was confirmed by a decrease in the number of enterprises themselves. 


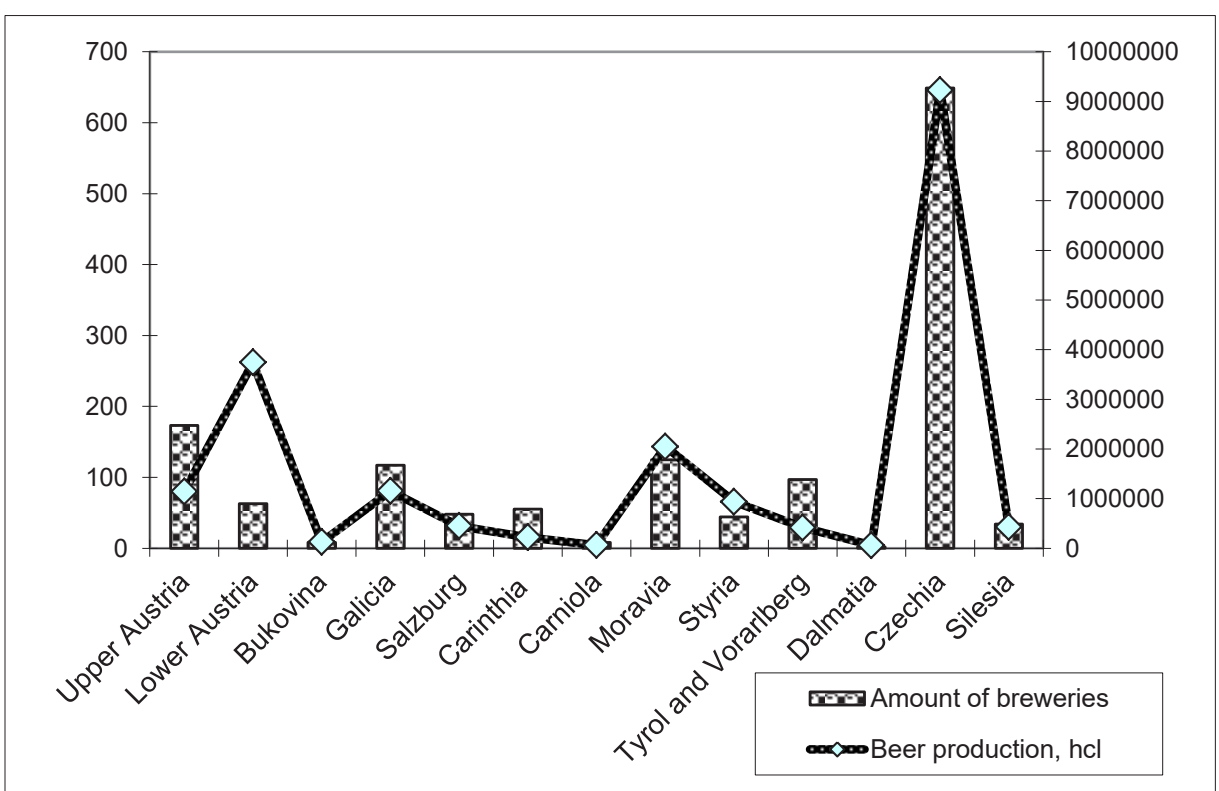

Figure 14. Producing of beer in Austria in 1900 (Pilat, 1904, p. 201)

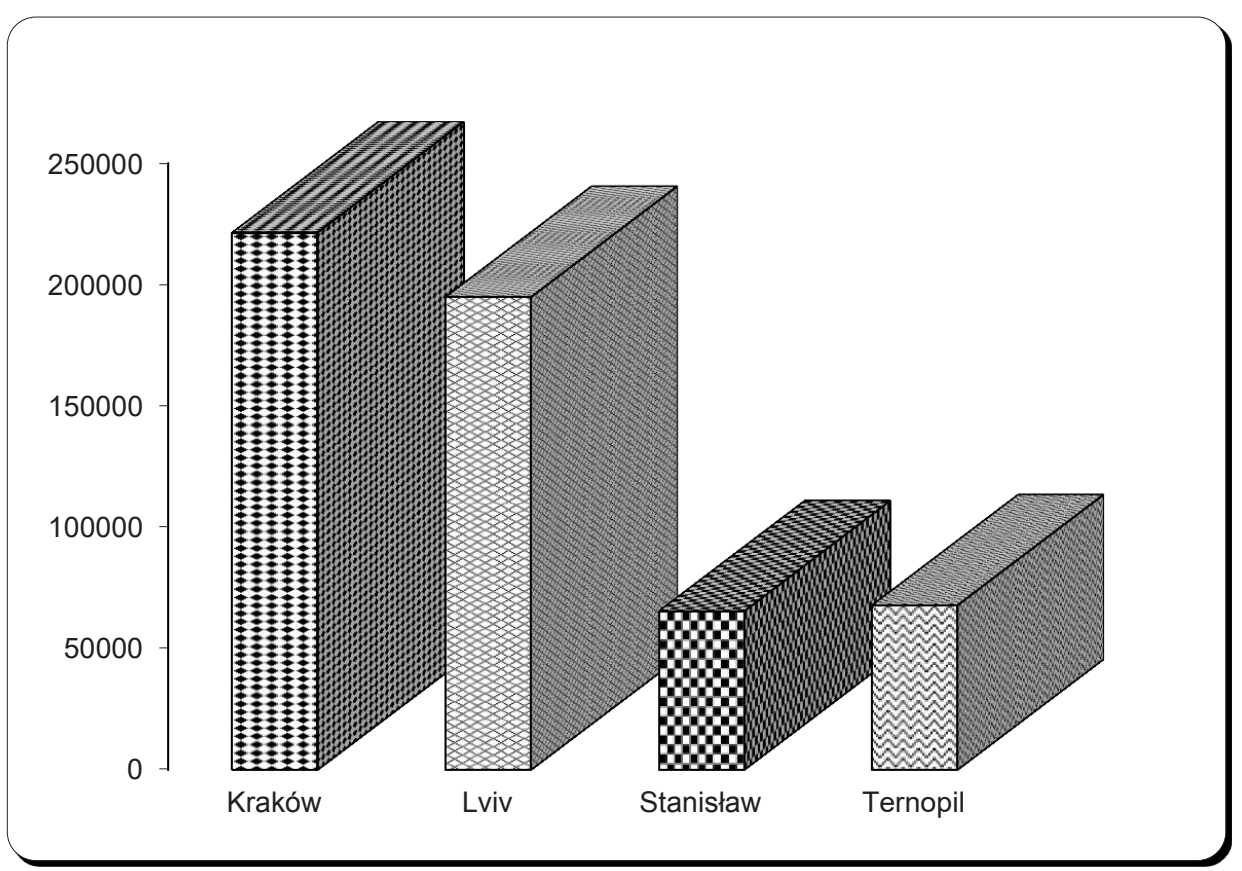

Figure 15. Beer production in Galicia, 1937, thshcl (Statystyka przemysłowa, 1938, pp. 58-68) 
Conclusions. In the middle of the XIX century there were over 300 primitive breweries. From 1847 to 1856 , their number decreased by a third at a stable output. From 1857 to 1865 , the number of breweries increased from 263 to 313 . The dramatic increase in output, which began with its increase by $45 \%$ in 1857 , peaked in 1865 , when it reached 692 thousand hcl of beer, in 2.8 times. Then there was a decrease in the number from 313 in 1865 to 101in 1907, that is, three times. At the same time, the output of finished products for the corresponding period increased from 588.5 to 1370 thousand hcl or 2.3 times. Productivity has increased by seven times. Proportionally to volumes of finished products, taking into account the features and sizes of tax legislation, there was a growth of paid taxes (1847 240 thousand zlr, $1871-1$ million zlr, $1899-2$ million zlr, $1907-2.6$ million zlr). In the $1847-1857$ breweries paid less than 1 zlr tax for produced 1 hcl of beer. In $1858-1859-$ $1,5 \mathrm{zlr}$, in 1865 - 1907 - almost 2 zlr.

In 1875, in comparison with previous years (this situation lasted from 1865), the number of breweries decreased from 237 in $1873-1874$ to 230 or $2.95 \%$. There was a tendency towards consolidation of enterprises, which displaced small unprofitable breweries. If in 1874 $35.6 \%$ of all breweries paid over 1000 zlr taxes, then in 1875 they remained only $25.63 \%$ of it. At the same time, the number of those who paid annually more than 10 thousand zlr increased $(10.43 \%$ versus $6.8 \%)$.

In the years of $1875-1878$, the number of breweries declined each year both in absolute terms and in the number of large enterprises. By the 1878, the number of breweries decreased in almost all districts, except for the city of Lviv and the district of Rzeszów. Of the total number of breweries in the campaign of $1877-1878,31 \%$ of enterprises paid less than 1,000 , $7 \%$ - more than 10,000 zlr. In parallel with the decrease in the number of breweries, there was a decrease in the production of beer (from 6.2 to 5.05 million liters) and the amount of taxes (from 1.12 to 0.93 million zlr). On average, one brewery produces $218-256 \mathrm{hcl}$ of beer, which was $8.4-10.61 /$ personannually. Decrease in beer production has led to a decrease in the total income of breweries by $20 \%$ (from 4.55 to 3703 million zlr).

Between 1876 and 1907, the number of breweries has steadily decreased, reaching 2.5 times in 30 years. From 1885 to 1900, the production of beer in Galicia doubled - from 582 to 1155 thousand hcl; the volume of production has grown annually by $40-60$ thousand hcl. Growth of the amount of taxes occurred in parallel with the output. During the relevant period, the amount increased from 1250 to 2156 thousand zlr or $72.5 \%$. The beginning of the XX century was marked by the inhibition of the growth of brewery production. In the years of 1901 - 1907, the production of beer grew by only $20 \%$, taxes - from 2131.4 to 2937.4 thousand zlr or $38 \%$.

In the 1920's there was a small amount of industrial breweries (41, 2054 workers) who produced more than 100 million liters of beer. Since the mid-1930s, the number of brewery has decreased to 34, a third of which has concentrated in the Lvivvoivodship. 1,600 people worked in the breweries (43 people per enterprise). During the 1930s, breweries and malting plants produced $630-750$ thousand hel of beer and maltannually, of which $80 \%$ consisted production of various sorts of beer.

The breweries of Galicia, having $10 \%$ of the enterprises, produced only $5 \%$ of the Austrian brewery production. More than $40 \%$ of all Austrian breweries were in the Czech Republic, which produced more than $42 \%$ of products. The share of Galicia in the total amount of Austro-Hungarian brewery was $4.1-4.3 \%$, and in the total amount of beer produced (almost 1.1 buckets $=2.65$ million liters). That isonly $4-5.25 \%$. The opposite trend was observed in 
providing beer per capita. In Salzburg, for one inhabitant, there were 3 buckets of beer, in Upper and Lower Austria 2-2.5, in the Czech Republic 1.6, then in Galicia this figure was only 0.2 bucket (2.5 liters). In 1875 Galicia produced beer in the amount of almost 6 million zlr.

At the turn of the century, more than 20 million hcl of beer was produced in 1423 breweries in Austria, from which Galicia accounted for only 5.75\% (1.15 million liters). This rate was the fourth after the Czech Republic (46.1\%), Lower Austria (18.7\%) and Moravia (10.22\%). The same place Galicia also occupied by the number of breweries. But the gross output did not characterize the real situation in the brewing region, because the average productivity of the Galician brewery was much lower than on other teritories of the state. Thus, one brewery in Lower Austria accounted for more than 59.4 thousand hcl of beer, more than 30.5 thousand hcl in Austrian Littoral, whilein Galicia - about 9.85 thousand hel ( 8 of 14 regions of Austria).

For production of beer per capita Galicia took one of the last places (15 1/ person), ahead of only the Kraina and the Austrian Littoral. Beer production in Salzburg ( $2.83 \mathrm{hcl} /$ person), Czech Republic (1.46 hcl / person) and Lower Austria (1.21 g / person) were the highest per capita.It should also be noted that Galicia produced per capita 7.7 liters of alcohol and only 15 liters of beer.

Funding. The authors received no financial support for the research, authorship, and/or publication of this article.

\section{BIBLIOGRAPHY}

Klapchuk V. M. (2015). Silske hospodarstvo Halychyny [The agriculture of Galychyna]: monohrafiya. Ivano-Frankivsk: Foliant. 336 p. [in Ukrainian].

Mały rocznik statystyczny [Small statistical yearbook]. (1930). Warszawa. 172 s. [in Polish].

Pilat T. (ed.). (1876). Wiadomości statystyczny o stosunkach krajowych [Statistical information about connections in districts]. Lwów: Druk. E. Winiarza. Rocznik 3. Z. I. 227 s. [in Polish].

Pilat T. (ed.). (1880). Wiadomości statystyczny o stosunkach krajowych [Statistical information about connections in districts]. Lwów: I Związkowa Drukarnia. Rocznik 5. Z. II. 245 s. [in Polish].

Pilat T. (ed.). (1901). Podręcznik Statystyki Galicyi [Textbook of statistics of Galicia]. Lwów: Pierwsza Związkowa Drukarnja. Tom VI. Cześć 2. 193-331. [in Polish].

Pilat T. (ed.). (1904). Podręcznik Statystyki Galicyi [Textbook of statistics of Galicia]. Lwów: Pierwsza Związkowa Drukarnja. Tom VII. Cześć 2. 187-325. [in Polish].

Pilat T. (ed.). (1908). Podręcznik Statystyki Galicyi [Textbook of statistics of Galicia]. Lwów: Pierwsza Związowa Drukarnja. Tom VIII. Cześć 2. 185-328. [in Polish].

Rutowski T. (ed.). (1898). Rocznik Statystyki Galicyi [Statistical yearbook of Galicia]. Lwów: Pierwsza Związkowa Drukarnja. Rok V. 369 s. [in Polish].

Rutowski T. (ed.). (1887). Rocznik Statystyki Galicyi [Statistical yearbook of Galicia]. Lwów: Drukarnja i Litografia Pillera i Spółki. Rok I. 296 s. [in Polish].

Rutowski T. (ed.). (1889). Rocznik Statystyki Galicyi [Statistical yearbook of Galicia]. Lwów: Pierwsza Zwiazkowa Drukarnja. Rok II. S. 317 s. [in Polish].

Rutowski T. (ed.). (1891). Rocznik Statystyki Galicyi [Statistical yearbook of Galicia]. Lwów: Pierwsza Związowa Drukarnja. Rok III. 328 s. [in Polish].

Rutowski T. (ed.). (1893). Rocznik Statystyki Galicyi [Statistical yearbook of Galicia]. Lwów: Pierwsza Związkowa Drukarnja. Rok IV. 388 s. [in Polish].

Statystyka przemystowa. 1933 [Industrial statistics]. (1935).Warszawa. Serja C. Zeszyt 18. $161 \mathrm{s.}$ [in Polish].

Statystyka przemysłowa. Produkcja i Zatrudnienie w Zakladach I-VII Kategorii. 1937[Industrial statistics. Production and employment in establishments I-VII categories]. (1938). Warszawa. Serja C. Zeszyt 97. 205 s. [in Polish].

The article was received on March 1, 2019. Article recommended for publishing 27/08/2019. 